\title{
Activation of focal adhesion kinase enhances the adhesion and invasion of pancreatic cancer cells via extracellular signal-regulated kinase- I/2 signaling pathway activation Hirozumi Sawai*, Yuji Okada, Hitoshi Funahashi, Yoichi Matsuo, Hiroki Takahashi, Hiromitsu Takeyama and Tadao Manabe
}

Address: Department of Gastroenterological Surgery, Nagoya City University Graduate School of Medical Sciences, Nagoya 4678601, Japan Email: Hirozumi Sawai* - cb8h-swi@asahi-net.or.jp; Yuji Okada - yuji@med.nagoya-cu.ac.jp; Hitoshi Funahashi - funa84@med.nagoyacu.ac.jp; Yoichi Matsuo - matsuo@med.nagoya-cu.ac.jp; Hiroki Takahashi - takahasi@med.nagoya-cu.ac.jp;

Hiromitsu Takeyama - takeyama@med.nagoya-cu.ac.jp; Tadao Manabe - mnb@med.nagoya-cu.ac.jp

* Corresponding author

Published: 06 October 2005

Molecular Cancer 2005, 4:37 doi:10.1 I86/1476-4598-4-37
Received: 12 September 2005

Accepted: 06 October 2005

This article is available from: http://www.molecular-cancer.com/content/4/1/37

(c) 2005 Sawai et al; licensee BioMed Central Ltd.

This is an Open Access article distributed under the terms of the Creative Commons Attribution License (http://creativecommons.org/licenses/by/2.0), which permits unrestricted use, distribution, and reproduction in any medium, provided the original work is properly cited.

\begin{abstract}
Background: Interaction with integrin and focal adhesion kinase (FAK) regulates the cancer cell adhesion and invasion into extracellular matrix (ECM). In addition, phosphorylation of FAK correlates with the increase of cell motility and invasion. Adhesion and spreading of cancer cells on a variety of ECM proteins, including collagen type IV (Coll IV), leads to an increase in tyrosine phosphorylation and activation of FAK. In this study, we investigated the mechanism of activation of FAK and its downstream extracellular signalregulated kinase (ERK)-I/2 signaling following stimulation by interleukin (IL)- I $\alpha$ and adhesion to ECM with subsequent enhancement of pancreatic cancer cell adhesion and invasion.
\end{abstract}

Results: In immunoblotting analysis, all three pancreatic cancer cell lines (AsPC-I, BxPC-3, and Capan-2) expressed the protein of FAK and $\beta_{1}$ integrin. Enhancement of FAK protein association with $\beta_{1}$ integrin when cells were plated on Coll IV was more increased by stimulation with IL-I $\alpha$. Preincubation with anti$\beta_{1}$ integrin antibody and FAK siRNA transfection inhibited the association of FAK with $\beta_{1}$ integrin of pancreatic cancer cells. FAK phosphorylation was observed by adhesion to Coll IV, furthermore, stronger FAK phosphorylation was observed by stimulation with IL-I $\alpha$ of pancreatic cancer cells adhered to Coll IV in time-dependent manner. Genistein, a tyrosine kinase inhibitor, markedly inhibited the FAK phosphorylation. IL-I $\alpha$ stimulation and Coll IV adhesion enhanced the activation of Ras, as evidenced by the increased Ras-GTP levels in pancreatic cancer cells. Activation of Ras correlated with the phosphorylation of ERK. While not statistical affecting the apoptosis of pancreatic cancer cells, IL-I $\alpha$ induced adhesion and invasion on Coll IV were inhibited with FAK gene silencing by siRNA, $\beta_{1}$ integrin blocking, and inhibition of FAK phosphorylation. PD98059, a MEK inhibitor, also inhibited IL-I $\alpha$-induced enhancement of adhesion and invasion in pancreatic cancer cells.

Conclusion: $\quad$ Our results demonstrated that activation of FAK is involved with the aggressive capability in pancreatic cancer through Ras/ERK signaling pathway. Based on our results, we suggest that the modification of IL-I, FAK, and integrins functions might be a novel therapeutic approach to aggressive spread of pancreatic cancer. 


\section{Background}

Integrin binding to extracellular matrix (ECM) protein or integrin crosslinking increases tyrosine phosphorylation of focal adhesion kinase (FAK) $[1,2]$. FAK is a tyrosine kinase considered a central molecule in integrin-mediated signaling, and it is involved in cellular motility and protection against apoptosis [3-7]. The carboxyl-terminal tyrosine residue ( $\mathrm{tyr}^{397}$ ) of FAK, constitutes a major site of phosphorylation, appears important for the tyrosine phosphorylation of focal complex associated proteins, and creates a high-affinity binding site recognized by the $\mathrm{SH}-2$ domain of the Src family $[8,9]$. In vitro, the N-terminal domain of FAK binds directly to peptides corresponding to the cytoplasmic domain of integrin $\beta$ subunits $[2,10]$. In addition, overexpression and phosphorylation of FAK correlates with the increase of cell motility and invasion $[4,5,11,12]$. Adhesion and spreading of cells on a variety of ECM proteins, including collagen type IV (Coll IV), leads to an increase in tyrosine phosphorylation and activation of FAK $[3,4,7]$. Furthermore, suppression of adhesion induced tyrosine phosphorylation of FAK may interrupt cancer cell-ECM interactions and affect the invasive and metastatic potential of cancer cells. Based on these results, considerable evidence points to a critical role of FAK participating in cancer cell-ECM interactions.

The integrin family ECM receptors are key mediators of cell proliferation and cell survival. Integrin-mediated cell adhesion is required for cell motility and also affects cell proliferation and invasion in many systems [13-15]. We previously proved that enhancement of $\alpha_{6} \beta_{1}$-integrin expression by interleukin (IL)- $1 \alpha$ acting through IL-1 receptor type I (IL-1RI) plays an important role in metastatic and invasive behaviors of pancreatic cancer, and that strong expression of $\alpha_{6}$ integrin in cancerous tissues significantly correlated with poor prognosis of pancreatic cancer patients $[15,16]$. $\beta_{1}$ integrin is also reported to play an important role in invasiveness and metastasis formation of cancer cells [17-19].

Integrin-ECM interactions also activate signaling cascades such as extracellular signal-regulated kinase-1/2 (ERK1/ $2)$, mitogen activated protein kinase (MAPK), phosphatidylinositol 3-kinase (PI3-K), and Akt [2-5,20-23]. Especially, the downstream targets of Ras signaling pathway are ERK1/2, which have been found to be regulated by activation of FAK with respect to different matrix components $[3,21,24]$. Therefore, integrin binding to the ECM creates and activates a bipartite kinase complex and transduces external stimuli from the ECM to the nucleus.

In this study, we investigated the mechanism of activation of FAK and its downstream ERK1/2 signaling following adhesion to ECM. Our results suggest that activation of FAK enhances the adhesive and invasive capabilities of pancreatic cancer cells through Ras/ERK signaling pathway.

\section{Results}

Expression of FAK and $\beta_{\text {I }}$ integrin in pancreatic cancer cells In immunoblotting analysis, all three pancreatic cancer cell lines also expressed FAK and $\beta_{1}$ integrin (Fig. 1A). In this study, we transfected all three pancreatic cancer cells with siRNA that specifically targets FAK. Downregulation of FAK protein expression by siRNA was confirmed by immunoblotting. Transfection of siRNA resulted in a near total loss of FAK expression (Fig. 1B).

\section{Interaction between $F A K$ and $\beta_{\text {I }}$ integrin}

In order to determine if FAK interacts with $\beta_{1}$ integrin subunit, $\beta_{1}$ integrin was immunoprecipitated from cell lysates of AsPC-1, BxPC-3, and Capan-2 cells and Western blotted using anti-FAK antibody. As shown Fig. 2, more FAK protein associated with $\beta_{1}$ integrin when cells were plated on Coll IV. Stimulation with recombinant human IL- $1 \alpha$ (rIL-1 $\alpha$ ) of pancreatic cancer cells on Coll IV furthermore enhanced the association of FAK with $\beta_{1}$ integrin. Preincubation with anti- $\beta_{1}$ integrin antibody and FAK siRNA inhibited the association of FAK with $\beta_{1}$ integrin of pancreatic cancer cells (Fig. 2).

\section{Phosphorylation of FAK was enhanced by Coll IV adhesion and IL-I $\alpha$ stimulation}

FAK activity was examined by FAK phosphorylation and total tyrosine phosphorylation in AsPC-1, BxPC-3, and Capan-2 cells. The lysates of pancreatic cancer cells were analyzed by immunoprecipitation with antibodies to FAK followed by Western blotting with an antibody which is specific for anti-phosphotyrosine (4G10). FAK activation was observed within $15 \mathrm{~min}$ of adhesion to Coll IV and remained high for $60 \mathrm{~min}$. (Fig. 3). Stronger FAK phosphorylation was observed by stimulation with rIL-1 $\alpha$ of pancreatic cancer cells adhered to Coll IV in time-dependent manner (Fig. 3). In contrast, incubation with Genistein, a tyrosine kinase inhibitor, markedly inhibited the FAK phosphorylation.

Effect of FAK gene silencing and $\beta_{1}$ integrin blocking on apoptosis of pancreatic cancer cells

After treated/untreated with FAK siRNA or control siRNA, pancreatic cancer cells were incubated with/without anti$\beta_{1}$ integrin antibody for $24 \mathrm{~h}$, and then terminal deoxynucleotidyl transferase-mediated nick end labeling (TUNEL) assay was performed to investigate whether knockdown of FAK expression and $\beta_{1}$ integrin blocking had any effects on pancreatic cancer apoptosis. Both FAK siRNA transfection and incubation with $\beta_{1}$ integrin antibody induced a slight increase in the apoptotic fraction of calls in normal culture conditions, however, there was no statistical difference among these treatments (Table 1). 
(A)

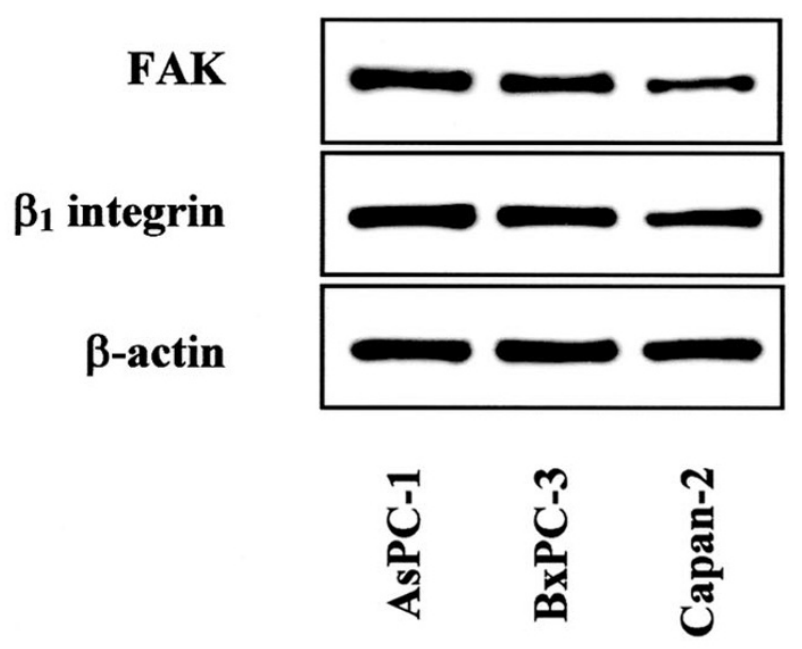

(B)

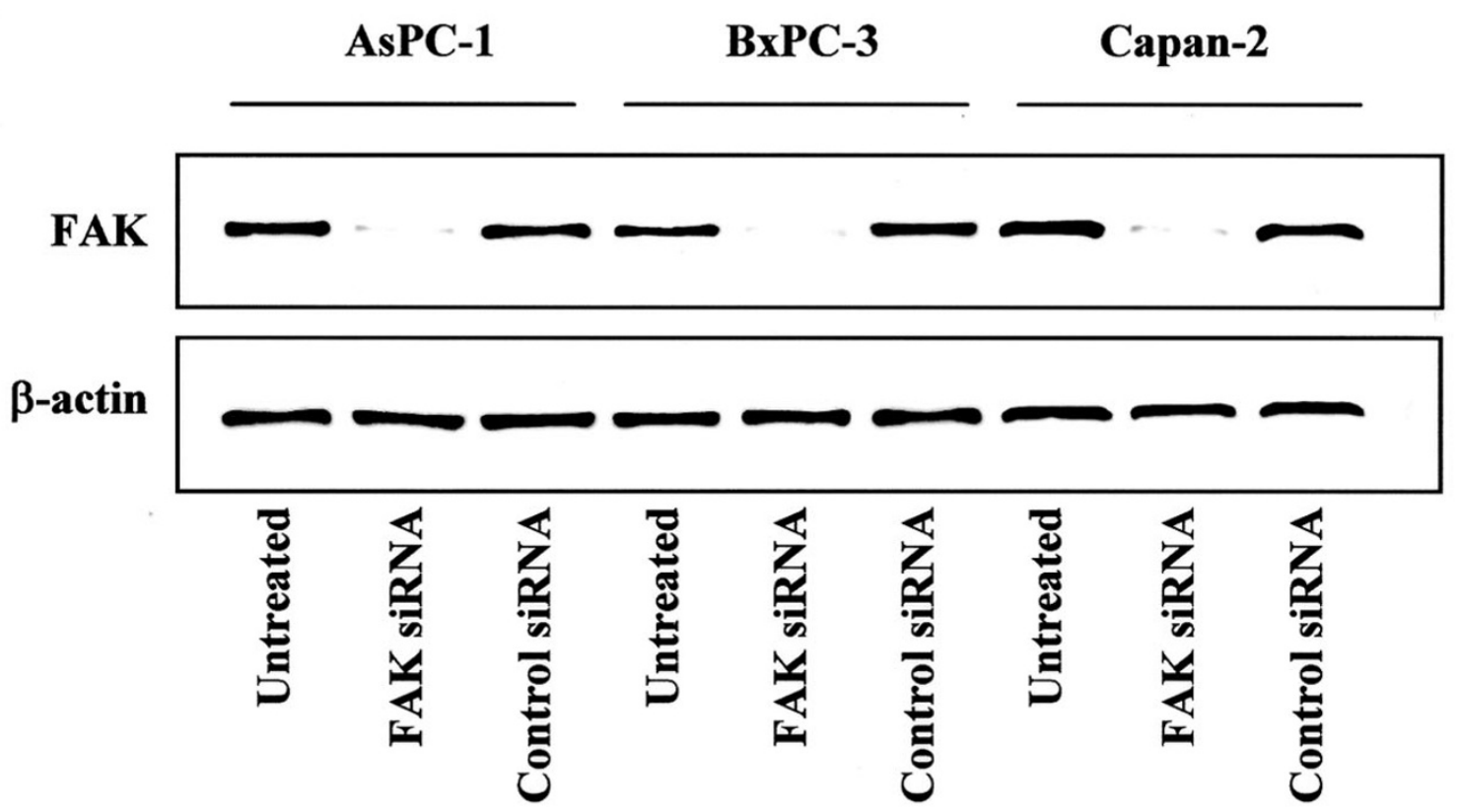

\section{Figure I}

Expression of FAK and $\beta_{1}$ integrin in pancreatic cancer cells. (A) FAK and $\beta_{1}$ integrin protein expression in pancreatic cancer cell lines was determined in whole cell lysates by Western blotting analysis. Fifty micrograms of total cell lysates was separated on $10 \%$ SDS-PAGE and transferred to polyvinylidene difluoride membranes. Membranes were probed with antibodies against FAK and $\beta_{1}$ integrin. The $\beta$-actin Western blot served as a loading control. (B) Knockdown of FAK expression by siRNA was confirmed by immunoblotting in all three pancreatic cancer cells. Re-probing with an anti- $\beta$-actin antibody served as a control. 

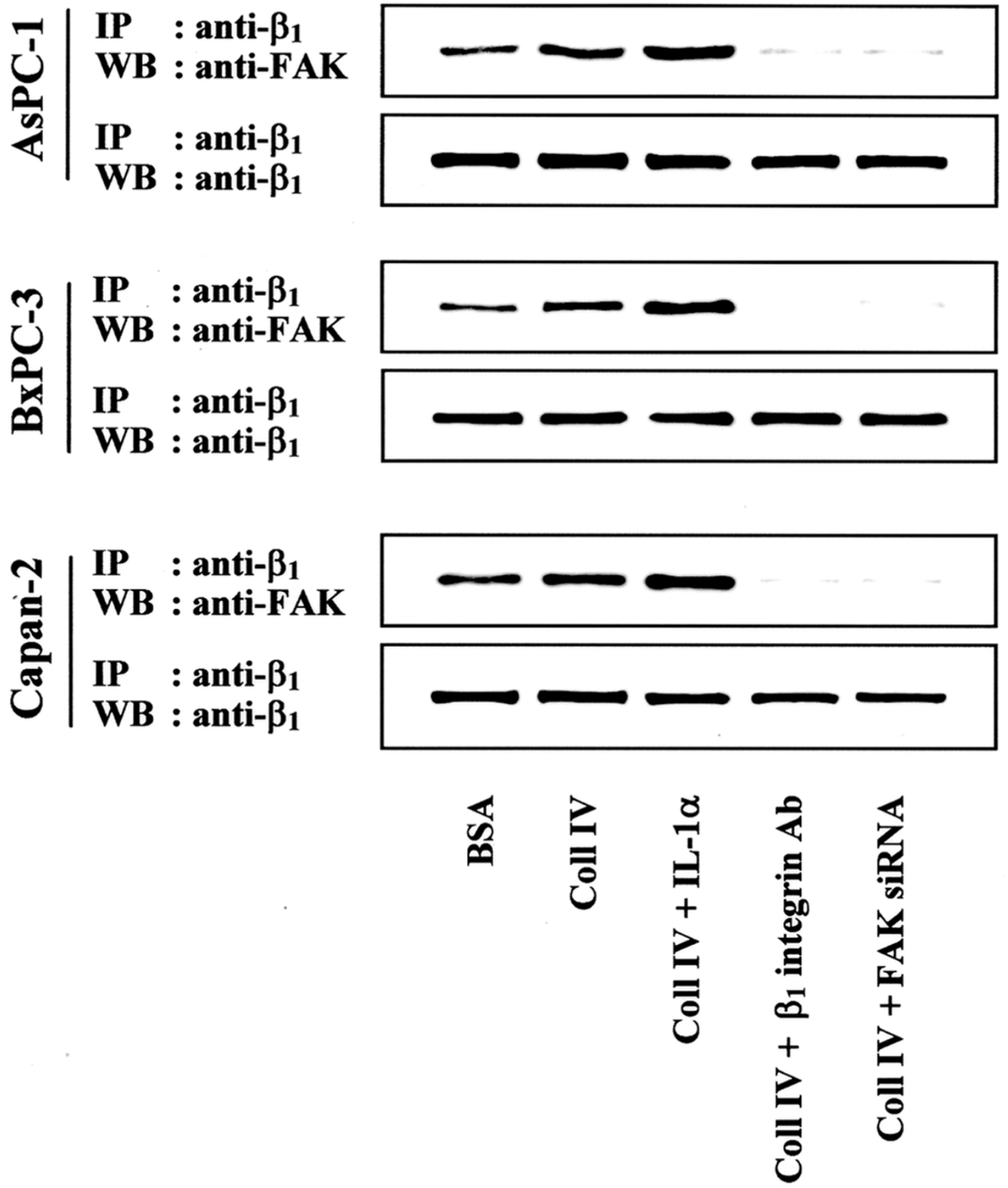

Figure 2

FAK and $\beta_{1}$ integrin subunit interaction in AsPC-I, BxPC-3, and Capan- 2 cells. After incubating on Coll IV with I0 ng/ml IL-I $\alpha$ or $0.5 \mu \mathrm{g} / \mathrm{ml}$ anti- $\beta_{\text {I }}$ integrin antibodies for $24 \mathrm{~h}$, cells were added $\left(2 \times 10^{5} \mathrm{cells} /\right.$ well $)$ to each well and incubated at $37^{\circ} \mathrm{C}$ and $5 \%$ $\mathrm{CO}_{2}$ for $30 \mathrm{~min}$. After removing unattached cells, total cell lysates were immunoprecipitated with antibodies against $\beta_{1}$ integrin subunit. Samples were resolved in $10 \%$ SDS-PAGE gel under nonreducing conditions and transferred to polyvinylidene difluoride membranes. Membranes were then probed with anti-FAK or anti- $\beta_{\text {I }}$ integrin antibodies. Samples from cells incubated on 3 $\%$ BSA were served as control. 

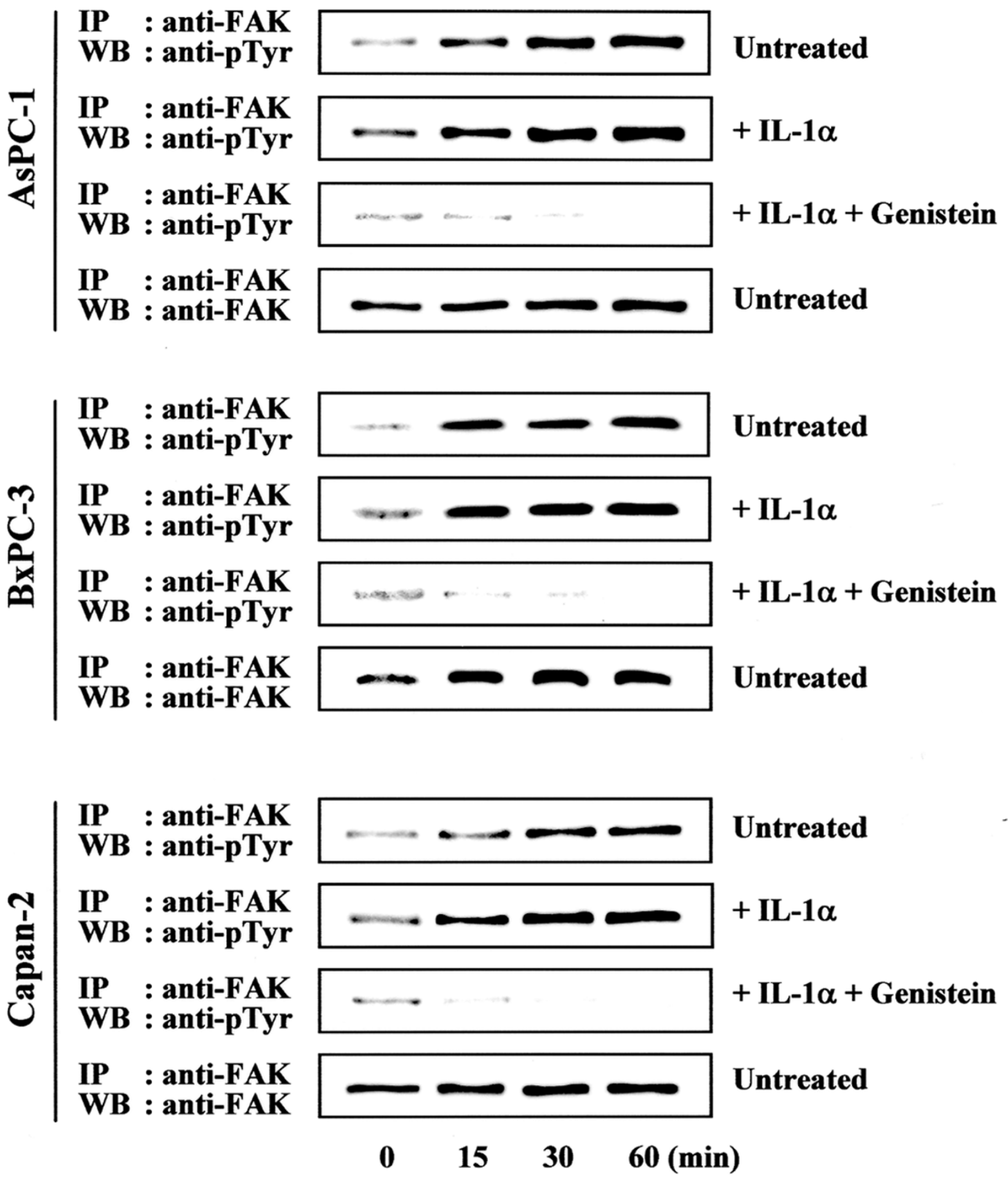

Figure 3

Phosphorylation of FAK in AsPC-I, BxPC-3, and Capan-2 cells. After incubating on Coll IV with I0 ng/ml IL-I $\alpha$ and/or $60 \mu M$ Genistein for $24 \mathrm{~h}$, cells were added $\left(2 \times 10^{5}\right.$ cells/well) to each well and incubated at $37^{\circ} \mathrm{C}$ and $5 \% \mathrm{CO}_{2}$ for 15,30, or 60 min. After removing unattached cells, cells were collected from each time point and lysed by lysis buffer and immunoprecipated with FAK antibody as described in Methods and materials. Effect of IL-I $\alpha$ and Genistein on Coll IV mediated phosphorylation of FAK was demonstrated. IP, immunoprecipitation; WB, Western blot. 


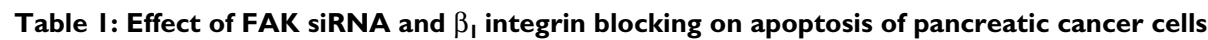

\begin{tabular}{ccccc}
\hline & & \multicolumn{2}{c}{ Apoptotic fraction (\%) } \\
\cline { 2 - 5 } Cell line & Untreated & Anti- $\beta_{\text {I }}$ integrin antibody & FAK siRNA & Control siRNA \\
\hline AsPC-1 & $1.37 \pm 0.33$ & $1.89 \pm 0.51$ & $2.20 \pm 0.66$ & $1.44 \pm 0.54$ \\
BxPC-3 & $1.99 \pm 0.31$ & $2.38 \pm 0.51$ & $2.56 \pm 0.53$ & $2.02 \pm 0.4$ \\
Capan-2 & $2.44 \pm 0.30$ & $2.59 \pm 0.37$ & $3.01 \pm 0.52$ & $2.50 \pm 0.43$ \\
\hline
\end{tabular}

AsPC-I, BxPC-3, and Capan-2 cells were treated with anti- $\beta_{1}$ integrin antibody, FAK siRNA, or control siRNA and incubated for $24 \mathrm{~h}$, and then detection of apoptosis was performed by TUNEL assay and flow cytometry. Statistical significance was tested by one-way analysis of variance and post hoc test (Turkey Kramer multiple comparisons). All data are expressed as mean \pm s.d. There was no significant difference among these treatments.

Involvement of FAK with adhesive and invasive capabilities of pancreatic cancer cells

We investigated whether the inhibition of FAK had any effects on adhesive and invasive response in pancreatic cancer cells. Knockdown of FAK expression with siRNA inhibited IL-1 $\alpha$-induced adhesion and invasion (Fig. 4A, $4 \mathrm{~B}$ ). The inhibitory antibodies against $\beta_{1}$ integrin subunit treatment similarly inhibited the IL- $\alpha$-induced enhancement of adhesion and invasion in all three pancreatic cancer cells. Genistein and PD98059 (a MEK inhibitor) also inhibited these enhancements of adhesion and invasion by IL- $1 \alpha$ stimulation in pancreatic cancer cells. While not statistical affecting cellular apoptosis, the basal adhesive and invasive capabilities of these cells were also suppressed by siRNA, anti- $\beta_{1}$ integrin antibody, Genistein, and PD98059 (Fig. 4A, 4B). DMSO vehicle had no effect on adhesion and invasion assays. These data suggest that FAK regulation and $\beta_{1}$ integrin subunit may have critical roles in adhesive and invasive capabilities of pancreatic cancer cells.

\section{Activation of Ras and ERK pathway after IL-I $\alpha$ stimulation and Coll IV adhesion}

We examined the activation of Ras/ERK pathway, a downstream target of FAK in pancreatic cancer cells, following adhesion of cells to Coll IV for 15, 30, or $60 \mathrm{~min}$. IL-1 $\alpha$ stimulation and Coll IV adhesion enhanced the activation of Ras, as evidenced by the increased Ras-GTP levels in three pancreatic cancer cell lines. Activation of Ras correlated with the phosphorylation of ERK. In contrast, IL-1 $\alpha$ stimulation and Coll IV adhesion did not induce the Akt phosphorylation (data not shown). These results indicate that IL- $1 \alpha$ and Coll IV adhesion may induce activation of ERK through a Ras-dependent pathway as a downstream of FAK activation (Fig. 5A). To evaluate whether FAK and $\beta_{1}$ integrin affect IL- $1 \alpha$-induced activation of Ras and ERK, pancreatic cancer cells were transfected with FAK siRNA or treated with anti- $\beta_{1}$ integrin antibody for $30 \mathrm{~min}$ before being exposed to rIL- $1 \alpha$ for 30 min on Coll IV. Inhibition FAK expression and $\beta_{1}$ integrin function inhibited the acti- vation of Ras and phosphorylation of ERK in three pancreatic cancer cell lines (Fig. 5B). These results suggest that expression of FAK and $\beta_{1}$-integrin has an important role in regulating IL-1 $\alpha$-induced activation of signaling pathways. Detection of total ERK 1/2 levels served as a loading control.

\section{Discussion}

In this report, we demonstrate that FAK plays a critical role in adhesive behavior of pancreatic cancer cells via activating the Ras/ERK signaling pathways. FAK protein association with $\beta_{1}$ integrin was increased when cells were attached on Coll IV and further increase was observed by stimulating with IL-1 $\alpha$. Knockdown of FAK expression with siRNA inhibited IL-1 $\alpha$-induced Ras/ERK activation with subsequent inhibition IL-1 $\alpha$-induced adhesion and invasion of pancreatic cancer cells on Coll IV while not statistical affecting cellular apoptosis.

The activation of FAK following cell adhesion to Coll IV and integrins engagement has been reported for many different cell types $[3,4,7,25-27]$. Recent reports have strongly implicated the FAK phosphorylation of lung cancer cells in adhesion to Coll IV [7]. In this study, the phosphorylation of FAK in pancreatic cancer cells was detectable with Coll IV adhesion in time-dependent manner. Furthermore, stronger FAK phosphorylation was observed by stimulation with IL- $1 \alpha$ of pancreatic cancer cells adhered to Coll IV. The tyrosine phosphorylation of FAK was suppressed by Genistein, which has been reported as a potent inhibitor of several tyrosine kinases. It can be suggested that Genistein inhibits the activities of protein tyrosine kinases (PTKs), which are active in the upstream of FAK signaling pathway. Considering the effect of Genistein on FAK phosphorylation, it can be suggested that the induction of FAK phosphorylation in pancreatic cancer cells may proceed primarily through the inhibition of a specific protein tyrosine phosphatase. For instance, a dual-specific phosphatase, PTEN, has been shown to be associated with FAK and capable of FAK 
(A)

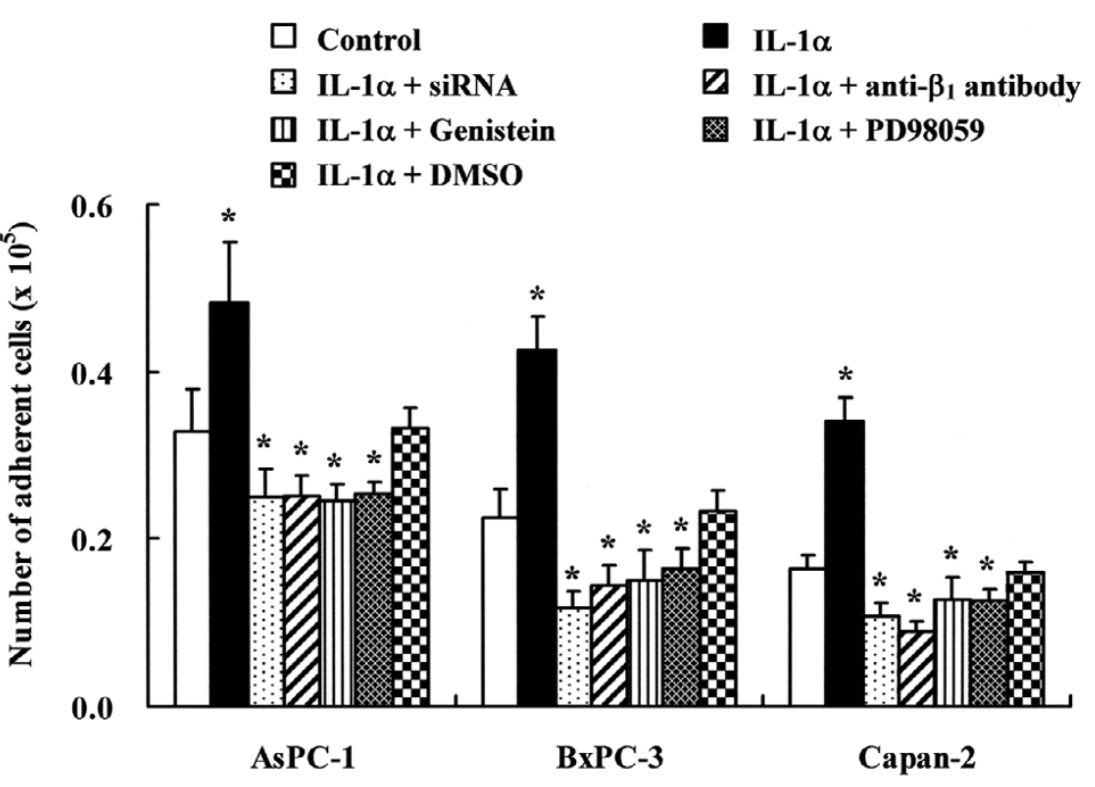

(B)
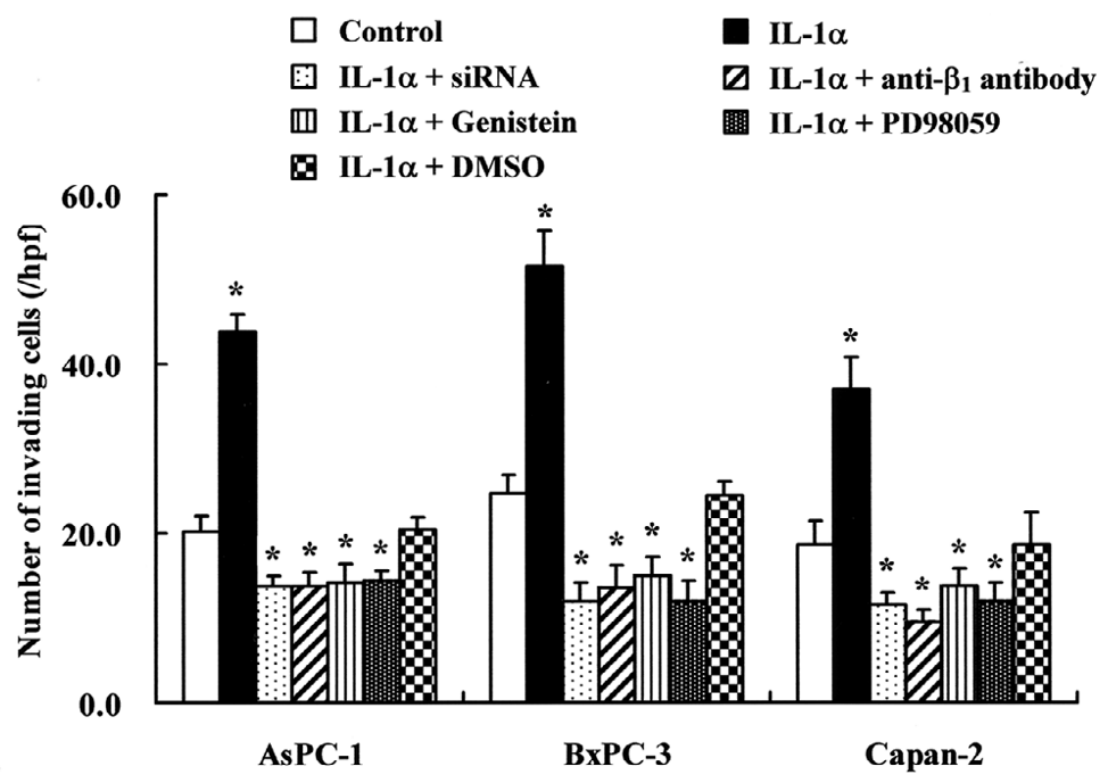

\section{Figure 4}

Involvement of FAK phosphorylation and integrin signaling with adhesion and invasion of pancreatic cancer cells. (A) AsPC-I, BxPC-3, and Capan-2 cells were incubated with $10 \mathrm{ng} / \mathrm{ml} \mathrm{IL-} \mid \alpha$, with $10 \mathrm{ng} / \mathrm{ml} I \mathrm{~L}-\mathrm{I} \alpha$ and $60 \mu \mathrm{M}$ Genistein, with $10 \mathrm{ng} / \mathrm{ml} \mathrm{rIL}-\mathrm{I} \alpha$ and $25 \mu \mathrm{M}$ PD 98059 , or with $10 \mathrm{ng} / \mathrm{ml}$ rlL- $\mathrm{I} \alpha$ and equivalent amounts of DMSO vehicle for $24 \mathrm{~h}$. FAK siRNA transfected cells were cultured with $10 \mathrm{ng} / \mathrm{ml} \mathrm{IL}$ - $\alpha$ for $24 \mathrm{~h}$. After incubating for $30 \mathrm{~min}$ with/without anti- $\beta_{\text {I }}$ antibody, cell adhesion assay was performed at $37^{\circ} \mathrm{C}$ for $30 \mathrm{~min}$. Statistical significance was tested by one-way analysis of variance and post hoc test (Turkey Kramer multiple comparisons). The $p$-values indicate statistical significance between data in controls and each treatment. Bars indicate the s.d.*: $p<0.05$. (B) After incubation for $30 \mathrm{~min}$ with/without antibody against $\beta_{1}$ integrin, AsPC-I, BxPC-3, and Capan-2 cells were cultured with $10 \mathrm{ng} / \mathrm{ml} \mathrm{IL-I} \alpha$, with $10 \mathrm{ng} / \mathrm{ml} \mathrm{IL-I} \alpha$ and $60 \mu \mathrm{M}$ Genistein, with $10 \mathrm{ng} / \mathrm{ml} \mathrm{rlL}-\mathrm{I} \alpha$ and $25 \mu \mathrm{M}$ PD98059, or with $10 \mathrm{ng} / \mathrm{ml} \mathrm{rlL-I} \alpha$ and equivalent amounts of DMSO vehicle for $24 \mathrm{~h}$ in the inner chamber coated with Coll IV. FAK siRNA transfected cells were cultured with $10 \mathrm{ng} / \mathrm{ml} \mathrm{IL-I} \alpha$ for $24 \mathrm{~h}$ in the inner chamber. Statistical significance was tested by one-way analysis of variance and post hoc test (Turkey Kramer multiple comparisons). The $p$-values indicate statistical significance between data in controls and each treatment. Bars indicate the s.d. $*: p<0.05$. 
(A)

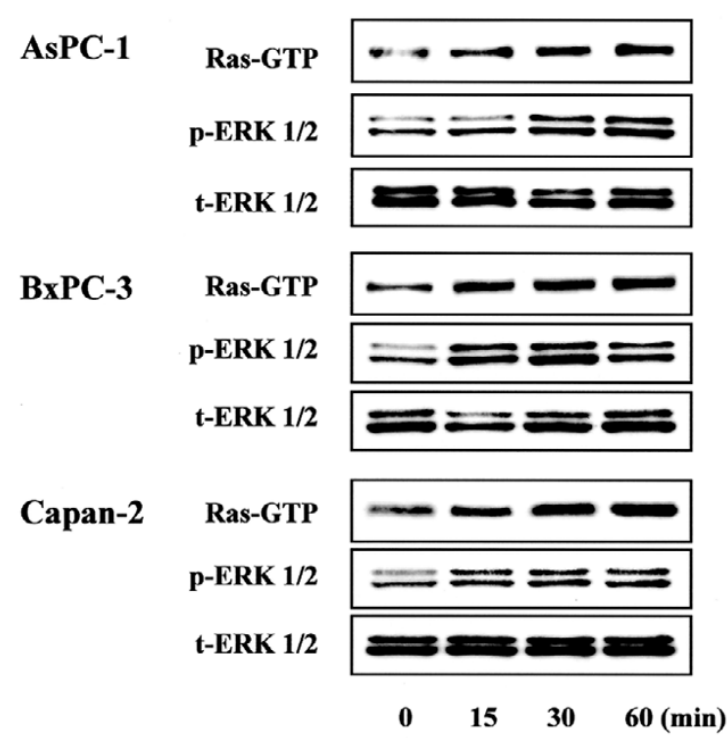

(B)

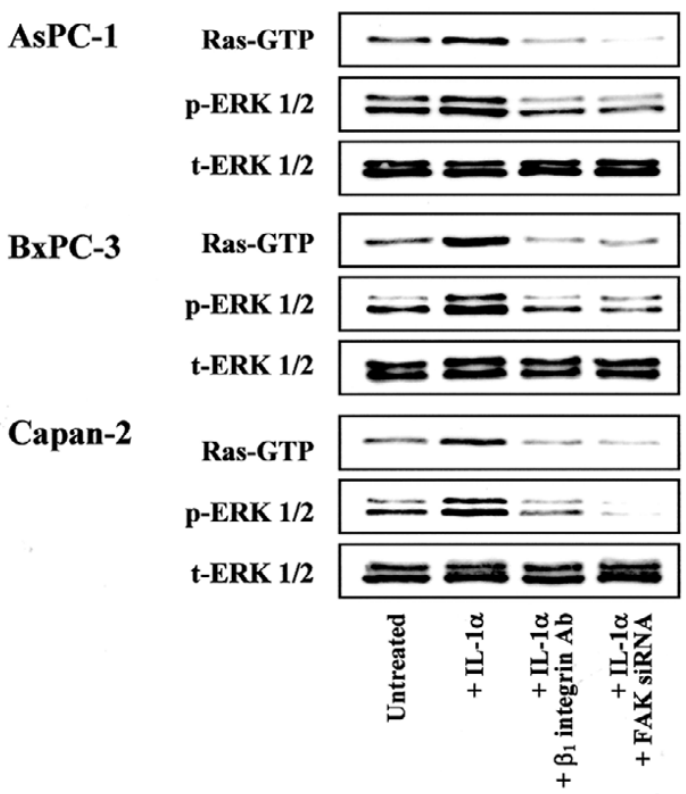

\section{Figure 5}

Involvement of FAK and $\beta_{\text {I }}$ integrin subunit with the activation of Ras and ERK pathway in pancreatic cancer cells. Examination of Ras and downstream ERK activation was performed as described in Materials and Methods. Cell lysates were prepared according to the instructions provided in the Ras Activation Assay Kit, and affinity precipitation of GTP-bound Ras was performed using GST-tagged Raf-RBD. Levels of pull-downed Ras (Ras-GTP) were determined by anti-Ras immunoblotting.(A) AsPC-I, BxPC-3, and Capan-2 cells were serum starved for $24 \mathrm{~h}$ and then attached to Coll IV with I0 ng/ml IL-I $\alpha$ for I5, 30 , or $60 \mathrm{~min}$. The time-dependent Ras activation and ERKI/2 phosphorylation by adhesion to Coll IV was demonstrated. Detection of total ERK I/2 levels served as a loading control.(B) AsPC-I, BxPC-3, and Capan-2 cells were serum starved for $24 \mathrm{~h}$ and then attached to Coll IV with $10 \mathrm{ng} / \mathrm{ml} \mathrm{IL-I} \alpha$ in the presence or absence of inhibitory antibodies against $\beta_{\text {I }}$ integrin subunit for 30 min. FAK siRNA transfected pancreatic cancer cells were attached to Coll IV with I0 ng/ml IL-I $\alpha$. Effects of IL-I $\alpha$, FAK gene silencing, and $\beta_{\text {I }}$ integrin blocking on the activation of Ras/ERK signaling pathway in pancreatic cancer cells were demonstrated. Detection of total ERK I/2 levels served as a loading control. 
dephosphorylation [28-30]. It would be interesting to determine whether PTEN is associated with FAK in cancer cells after adhesion to Coll IV.

There is accumulating evidence that supports an important role of ERK pathway in promoting cell proliferation and invasion of cancer cell [4,31-35]. It has been reported in many cell lines that integrin dependent activation of MAPK requires FAK $[24,36,37]$. Coll IV-dependent activation of ERK1/2 in intestinal epithelial cells also requires FAK [3]. MAPK has been reported to regulate cell migration through the enhancement of myosin light chain phosphorylation [38]. Thus, the requirement for FAK activity in the efficient activation of MAPK could also be related to the effects of FAK on cell motility $[39,40]$. In addition, previous studies have indicated that loss of integrin signaling, such as FAK gene silencing and blocking of integrin signaling, can induce cellular apoptosis[14,20,41-44]. In contrast, these suppress of integrin signaling is reported to decrease the invasive behavior but not cellular apoptosis and proliferation in some cancer cells $[2,45]$. In this study, the similarity in the time course over which FAK and ERK1/2 were activated in response to IL-1 $\alpha$ and adhesion to Coll IV of pancreatic cancer cells were observed. Both of knockdown of FAK expression with siRNA and blocking of $\beta_{1}$ integrin inhibited IL- $1 \alpha$ induced Ras/ERK activation with subsequent inhibition IL- $1 \alpha$-induced adhesion and invasion of pancreatic cancer cells on Coll IV while not statistical affecting cellular apoptosis. Furthermore, we demonstrated that a MEK inhibitor PD98059 inhibited IL- $1 \alpha$-induced enhancement of adhesion and invasion in pancreatic cancer cells. Our results reveal that the relationship between FAK phosphorylation and the activation of its downstream Ras/ERK signaling pathway has an important role in the adhesive and invasive capabilities of pancreatic cancer cells. It has also been reported that IL-1 plays an important role in tumor invasion and angiogenesis [46-48]. Furthermore, recent reports demonstrated the involvement of IL- 1 with the ERK1/2 signaling pathway activation [49-51]. Our results in this work are supported with these reports.

Integrin mediated signaling to ERK1/2 is dependent on the integrity of the actin cytoskeleton $[52,53]$. The disruption of cytoskeleton integrity completely inhibited fibronectin stimulated FAK tyrosine phosphorylation and ERK1/2 signaling. Also, in some cancer cells, the integrity of the cytoskeleton structure is required for ECM generated signals to ERK1/2. $\beta_{1}$ integrin is reported to play an important role in adhesion and invasion of cancer cells [17-19]. And several intracellular signals have been suggested to mediate effects of IL-1, including activation of MAPK. Activation of MAPK by IL-1 subsequently induces the activator protein-1 and nuclear factor-KB DNA-binding activity, which promotes expression of the genes involved in cell survival, proliferation, and angiogenesis $[54,55]$. We also previously reported that the enhancement of $\alpha_{6} \beta_{1}$-integrin expression by IL- $1 \alpha$ acting through IL-1RI plays a critical role in adhesive and invasive behaviors in pancreatic cancer, and proved that the strong expression of the $\alpha_{6}$ integrin subunit in pancreatic cancer tissue significantly correlated with the poor prognosis and the presence of hepatic metastases in pancreatic cancer patients $[15,16]$. In this study, we investigated whether $\beta_{1}$ integrin is physically associated with FAK or the activation of $\beta_{1}$ integrin mediated signaling is sufficient to activate FAK in pancreatic cancer cells. We demonstrated that the enhancement of adhesion and invasion to Coll IV in pancreatic cancer cells is dependent on the presence of $\beta_{1}$ integrin. Furthermore, we proved that FAK phosphorylation correlated with the activation of its downstream Ras/ ERK signaling pathway. Our data indicates that the Coll IV-induced phosphorylation of FAK correlated with physical association of FAK with $\beta_{1}$ integrin with subsequent the activation of ERK1/2 signaling pathways in pancreatic cancer cells.

\section{Conclusion}

We demonstrated that IL- $1 \alpha$ stimulation and cell adhesion to Coll IV enhanced the FAK protein association with $\beta_{1}$ integrin and FAK phosphorylation. And these enhancements correlated with the activation of Ras/ERK signaling pathways in pancreatic cancer cells. IL-1 $\alpha$-induced activation of these signaling pathways can be inhibited by knockdown of FAK expression with siRNA, consistent with the inhibition of adhesive and invasive capabilities of pancreatic cancer cells. Based on these results, we suggest that the modification of IL-1, FAK, and integrins functions might be a novel therapeutic approach to aggressive spread of pancreatic cancer.

\section{Methods \\ Cell culture}

The human pancreatic cancer cell lines, AsPC-1, BxPC-3 and Capan-2, were provided from the American Type Culture Collection (Rockville, MD, USA). The AsPC-1 and BxPC-3 cells were maintained in RPMI 1640 (Gibco BRL, Eggenstein, Germany) supplemented with $10 \%$ fetal calf serum (FCS). Capan-2 cells were maintained in Dulbecco modified Eagle medium (Gibco BRL) with high glucose and $10 \%$ fetal calf serum. All cells were incubated at $37^{\circ} \mathrm{C}$ in a humidified atmosphere of $5 \% \mathrm{CO}_{2}$ in air.

\section{Reagents and Antibodies}

rIL-1 $\alpha$ was provided by Diaclone (Besançon, France). Coll IV (human) and Genistein were purchased from SIGMA (Saint Louis, MO, USA). PD98059 was purchased from New England Biolabs Inc (Beverly, MA, USA). The monoclonal antibodies used included anti- $\beta 1$ (P5D2) from Chemicon International Inc. (Temecula, CA, USA); 
anti-phosphotyrosine (4G10) and anti-FAK (4.47) from Upstate Biotechnology Inc. (Lake Placid, NY, USA). The polyclonal anti-phospho-Akt (587F11), anti-phosphoERK $1 / 2$ and anti-ERK $1 / 2$ antibodies were from Cell Signaling Technology (Beverly, MA, USA).

\section{Western blot analysis}

Cells were lysed in lysis buffer ( $50 \mathrm{mM}$ Tris-HCl, $\mathrm{pH} 7.5$, $150 \mathrm{mM} \mathrm{NaCl}, 1 \mathrm{mM} \mathrm{CaCl} 2,1 \%$ Triton X-100, $0.1 \%$ SDS, $0.1 \%$ Nonidet P-40, $2 \mathrm{mM}$ PMSF, $1 \mathrm{mM}$ vanadate, $5 \mu \mathrm{g} /$ $\mathrm{ml}$ Trasylol, $10 \mu \mathrm{M}$ Pepstatin A and $10 \mu \mathrm{M}$ leupeptin). Protein concentrations were determined with a BCA protein assay kit (Pierce, Rockford, IL, USA). The amounts of samples were $50 \mu \mathrm{g}$ per each lane. Lysates were separated by $10 \%$ SDS-polyacrylamide gel electrophoresis (SDSPAGE), transferred to polyvinylidene difluoride membranes (Immobilon PVDF; Nihon Millipore Ltd., Tokyo, Japan) and immunoblotted with each antibody. $\beta$-actin Western blots were served as controls.

\section{Immunoprecipitation}

Pancreatic cancer cells lysates were centrifuged at 14,000 $\mathrm{rpm}$ at $4{ }^{\circ} \mathrm{C}$ for $15 \mathrm{~min}$ and the supernatants $(750 \mu \mathrm{g}$ of protein) were used for immunoprecipitation with either anti- $\beta 1$ integrin (P5D2) or anti-FAK (4.47) antibody at $4^{\circ} \mathrm{C}$ overnight. After incubation for $1 \mathrm{~h}$ with antibody, either protein A- or protein G-sepharose was added to the lysates and incubated overnight at $4{ }^{\circ} \mathrm{C}$. The bead bound complexes were pelleted, washed several times with lysis buffer in PBS and boiled with SDS sample buffer for $5 \mathrm{~min}$ before loading on $10 \%$ SDS-PAGE. For Western blot analysis, the proteins were transferred to polyvinylidene difluoride membranes after SDS-PAGE Specific binding was detected with the enhanced chemiluminescence system (ECL; Amersham Life Science Ltd., Buckinghamshire, United Kingdom).

\section{RNA interference (siRNA)}

Pancreatic cancer cells were transfected with siRNA for FAK and with control nonspecific siRNA using FAK siRNA/siAb ${ }^{\mathrm{TM}}$ Assay Kits (Upstate Biotechnology Inc.) according to the manufacture's instruction. Briefly, cells were grown in $35 \mathrm{~mm}$ dishes and overlaid with the transfection mixture containing siRNA at a concentration of $200 \mathrm{pmol} /$ well. After $4 \mathrm{~h}$ incubation, complete medium with $10 \%$ FCS was added and cells were incubated for another $48 \mathrm{~h}$.

\section{TUNEL assay}

Detection of apoptosis was performed by TUNEL assay. After incubating for $24 \mathrm{~h}$ with/without anti- $\beta_{1}$ integrin antibody, pancreatic cancer cells were collected by centrifugation, fixed in $4 \%$ paraformaldehyde ( $\mathrm{pH} 7.4)$ and then stained and analyzed for apoptosis using an In Situ Cell Death Detection Kit, Fluorescein (Roche Diagnostics
GmbH, Penzburg, Germany). Fixed cells were permeabilized using a mixture containing terminal deoxynucleotidyltransferase and fluorescein-dUTP at $37^{\circ} \mathrm{C}$ for $60 \mathrm{~min}$. Flow cytometric analysis using a FACS scan (Becton Dickinson Immunocytometry Systems, Mountain View, CA, USA) was done to quantitate apoptosis[56].

\section{Cell adhesion assay}

Adhesion assay was performed as described previously with some modifications [15]. 24-well plates were coated either with Coll IV $\left(5.0 \mu \mathrm{g} / \mathrm{cm}^{2}\right)$ or $3 \%$ bovine serum albumin (BSA) in phosphate-buffered saline (PBS). Briefly, after incubating for $24 \mathrm{~h}$ with/without rIL-1 $\alpha$ (10 $\mathrm{ng} / \mathrm{ml})$, Genistein $(60 \mu \mathrm{M})$, PD98059 $(25 \mu \mathrm{M})$, or equivalent amounts of DMSO vehicle, cells were added $\left(2 \times 10^{5}\right.$ cells/well) to each well and incubated at $37^{\circ} \mathrm{C}$ and $5 \%$ $\mathrm{CO}_{2}$ for 15, 30, or $60 \mathrm{~min}$. After removing unattached cells, the number of adherent cells was counted directly by light microscopy. Before the stimulating experiments with IL- $1 \alpha$ were attempted, a concentration of $10 \mathrm{ng} / \mathrm{ml}$ was determined to be the lowest effective concentration for stimulating experiments (data not shown). In some experiments, $0.5 \mu \mathrm{g} / \mathrm{ml}$ anti- $\beta_{1}$ integrin antibodies were added to cells for $30 \mathrm{~min}$ prior to seed to the well. Before the blocking experiments were attempted, a concentration of $0.5 \mu \mathrm{g} / \mathrm{ml}$ was determined to be the lowest effective concentration for blocking experiments (data not shown). Experiments were performed in triplicate and repeated at least three times.

\section{Cell invasion Assay}

In vitro invasion assays were performed as described previously with some modifications [15]. Polycarbonate filters (6.3-mm diameter, $8-\mu \mathrm{m}$ pore size) of cell culture inserts (BD Biosciences Discovery Labware, Franklin Lakes, NJ, USA) were coated with $5.0 \mu \mathrm{g} / \mathrm{cm}^{2}$ Coll IV. Cancer cells were added $\left(1 \times 10^{5}\right.$ cells/well $)$ to the inner chamber of a cell culture insert and incubated at $37^{\circ} \mathrm{C}$ for $24 \mathrm{~h}$, either with $10 \mathrm{ng} / \mathrm{ml} \mathrm{rIL-} 1 \alpha$, with $10 \mathrm{ng} / \mathrm{ml} \mathrm{rIL-} 1 \alpha$ and 60 $\mu \mathrm{M}$ Genistein, with $10 \mathrm{ng} / \mathrm{ml} \mathrm{rIL}-1 \alpha$ and $0.5 \mu \mathrm{g} / \mathrm{ml}$ of anti$\beta_{1}$ integrin antibody, with $10 \mathrm{ng} / \mathrm{ml} \mathrm{rIL-} 1 \alpha$ and $25 \mu \mathrm{M}$ PD98059, or with $10 \mathrm{ng} / \mathrm{ml}$ rIL- $1 \alpha$ and equivalent amounts of DMSO vehicle. To quantitate invasion, the filters were fixed in $70 \%$ ethanol for $30 \mathrm{~min}$ and stained with Giemsa. Cells were removed from the upper surface of the filters by rubbing gently with a cotton-tipped applicator. Cells that had invaded through the membrane were counted in five random microscope fields of the lower filter surface.

\section{Ras activation assay}

Ras activation state was determined using the Ras Activation Assay Kit provided from Upstate. Briefly, after serum starved for $24 \mathrm{~h}$, pancreatic cancer cells were incubated on the $35-\mathrm{mm}$ well coated with Coll IV $\left(5.0 \mu \mathrm{g} / \mathrm{cm}^{2}\right)$ in 
serum-free medium with/without rIL-1 $\alpha(10 \mathrm{ng} / \mathrm{ml})$ for 15,30 , or $60 \mathrm{~min}$. Then, cells were harvested and lysed in lysis buffer (100 mM HEPES, pH 7.5, $200 \mathrm{mM} \mathrm{NaCl}, 1 \%$ Nonidet P-40, $10 \mathrm{mM} \mathrm{MgCl}_{2}, 5 \mathrm{mM}$ EDTA and $10 \%$ glycerol), and supernatant prepared by centrifugation for 5 $\min$ at $4^{\circ} \mathrm{C}$ at $14,000 \mathrm{~g}$. Ras-GTP from various treated lysates was "pulled down" using the GST fusion protein corresponding to human Ras binding domain of Raf-1 bound to agarose. The presence of Ras-GTP was detected by Western blotting using anti-Ras antibody (Upstate). In some experiments, $0.5 \mu \mathrm{g} / \mathrm{ml}$ anti- $\beta_{1}$ integrin antibodies were added to cells for $30 \mathrm{~min}$ prior to seed to the well.

\section{Statistical analysis}

Statistical comparisons were made using the Student's $t$ test for paired observations or by one-way ANOVA with a post hoc test for multiple comparisons. Statistical significance was indicated by $p<0.05$. Data are presented as mean \pm standard deviation (s.d.). Each experiment was repeated 3 times and was carried out in triplicate.

\section{Abbreviations}

ECM, extracellular matrix; FAK, focal adhesion kinase; Coll IV, collagen type IV; IL, interleukin; IL-1RI, IL-1 receptor type I; ERK, extracellular signal-regulated kinase; MAPK, mitogen activated protein kinase; PI3-K, phosphatidylinositol 3-kinase; TUNEL, deoxynucleotidyl transferase-mediated nick end labeling; PTK, protein tyrosine kinase; FCS, fetal calf serum; SDS-PAGE, SDS-polyacrylamide gel electrophoresis; BSA, bovine serum albumin; PBS, phosphate-buffered saline.

\section{Authors' contributions}

HS carried out the Western blots, immunoprecipitations, and the investigation of Ras activity in addition to the drafting of the manuscript. YO and HF contribute the adhesion and invasion assays and statistical analyses. YM and $\mathrm{TH}$ performed the cell culture, adhesion assay, and the literature search. HT designed the experiments and contributed to the writing of the manuscript. TM conceived the project and aided in experimental design. All authors read and approved the final manuscript.

\section{References}

I. Richardson A, Parsons JT: A mechanism for regulation of the adhesion-associated protein tyrosine kinase ppI25FAK. Nature 1996, 380:538-540.

2. Brockbank EC, Bridges J, Marshall CJ, Sahai E: Integrin betal is required for the invasive behavior but not proliferation of squamous cell carcinoma cells in vivo. $\mathrm{Br} J$ Cancer 2005, 92:102-112.

3. Sanders MA, Basson MD: Collagen IV-dependent ERK activation in human Caco-2 intestinal epithelial cells requires focal adhesion kinase. J Biol Chem 2000, 275:38040-38047.

4. Crowe DL, Ohannessian A: Recruitment of focal adhesion kinase and paxillin to $\beta$ I integrin promotes cancer cell migration via mitogen activated protein kinase activation. BMC Cancer 2004, 4:18.

5. Schmitz KJ, Grabellus F, Callies R, Otterbach F, Wohlschlaeger J, Levkau B, Kimmig R, Schmid KW, Baba HA: High expression of focal adhesion kinase ( $\mathrm{p} / 25_{\mathrm{FAK}}$ ) in node-negative breast cancer is related to overexpression of HER-2/neu and activated Akt kinase but does not predict outcome. Breast Cancer Res 2005, 7:RI94-R203.

6. Kirsch $\mathrm{K}$, Kensinger $\mathrm{M}$, Hanafusa $\mathrm{H}$, August $\mathrm{A}$ : A pl 30 Cas tyrosine phosphorylated substrate domain decoy disrupts v-Crk signaling. BMC Cell Biol 2002, 3:18.

7. Mukhopadhyay NK, Gordon GJ, Chen CJ, Bueno R, Sugarbaker DJ, Jaklitsch MT: Activation of focal adhesion kinase in human lung cancer cells involves multiple and potentially parallel signaling events. J Cell Mol Med 2005, 9:387-397.

8. Gilmore AP, Romer LH: Inhibition of focal adhesion kinase (FAK) signaling in focal adhesions decreases cell motility and proliferation. Mol Biol Cell 1996, 7:I209-I224.

9. Richardson A, Malik RK, Hildebrand JD, Parsons JT: Inhibition of cell spreading by expression of the C-terminal domain of focal adhesion kinase (FAK) is rescued by coexpression of Src or catalytically inactive FAK: a role for paxillin tyrosine phosphorylation. Mol Cell Bio 1997, 17:6906-69|4.

10. Schaller MD, Otey CA, Hildebrand JD, Parsons JT: Focal adhesion kinase and paxillin bind to peptides mimicking beta integrin cytoplasmic domains. J Cell Biol 1995, 130:1 I81-1 I87.

II. Fujii T, Koshikawa K, Nomoto S, Okochi O, Kaneko T, Inoue S, Yatabe $Y$, Takeda S, Nakao A: Focal adhesion kinase is overexpressed in hepatocellular carcinoma and can be served as an independent prognostic factor. J Hepatol 2004, 4 I: I 04- I II.

12. Caceres M, Guerrero J, Martinez J: Overexpression of RhoA-GTP induces activation of the Epidermal Growth Factor Receptor, dephosphorylation of focal adhesion kinase and increased motility in breast cancer cells. Exp Cell Res 2005, 309:229-238.

13. Schwartz MA, Assoian RK: Integrins and cell proliferation: regulation of cyclin-dependent kinases via cytoplasmic signaling pathways. J Cell Sci 200I, I I 4:2553-2560.

14. Hynes RO: Integrins: bidirectional, allosteric signaling machines. Cell 2002, I 1 0:673-687.

15. Sawai H, Funahashi H, Yamamoto M, Okada Y, Hayakawa T, Tanaka $M$, Takeyama $H$, Manabe $T$ : Interleukin-I $\alpha$ enhances integrin $\alpha_{6} \beta_{1}$ expression and metastatic capability of human pancreatic cancer. Oncology 2003, 65:167-173.

16. Sawai H, Funahashi H, Matsuo Y, Yamamoto M, Okada Y, Hayakawa $T$, Manabe T: Expression and prognostic roles of integrins and interleukin- $I$ receptor type $I$ in patients with ductal adenocarcinoma of the pancreas. Dig Dis Sci 2003, 48: I 24I-I 250.

17. van Golen CM, Soules ME, Grauman AR, Feldman EL: N-Myc overexpression leads to decreased beta $\mathrm{I}$ integrin expression and increased apoptosis in human neuroblastoma cells. Oncogene 2003, 22:2664-2673.

18. White DE, Kurpios NA, Zuo D, Hassell JA, Blaess S, Mueller U, Muller W]: Targeted disruption of betal-integrin in a transgenic mouse model of human breast cancer reveals an essential role in mammary tumor induction. Cancer Cell 2004, 6: I 59- 170.

19. Seales EC, Jurado GA, Brunson BA, Wakefield JK, Frost AR, Bellis SL: Hypersialylation of betal integrins, observed in colon adenocarcinoma, may contribute to cancer progression by upregulating cell motility. Cancer Res 2005, 65:4645-4652.

20. Buda A, Qualtrough D, Jepson MA, Martines D, Paraskeva C, Pignatelli M: Butyrate downregulates alpha2betal integrin: a possible role in the induction of apoptosis in colorectal cancer cell lines. Gut 2003, 52:729-734.

21. Harnois C, Demers MJ, Bouchard V, Vallee K, Gagne D, Fujita N, Tsuruo T, Vezina A, Beaulieu JF, Cote A, Vachon PH: Human intestinal epithelial crypt cell survival and death: Complex modulations of Bcl-2 homologs by Fak, PI3-K/Akt-I, MEK/Erk, and p38 signaling pathways. J Cell Physiol 2004, 198:209-222.

22. Leung-Hagesteijn C, Hu MC, Mahendra AS, Hartwig S, Klamut HJ, Rosenblum ND, Hannigan GE: Integrin-linked kinase mediates bone morphogenetic protein 7-dependent renal epithelial cell morphogenesis. Mol Cell Biol 2005, 25:3648-3657.

23. Shirk AJ, Kuver R: Epidermal growth factor mediates detachment from and invasion through collagen $I$ and Matrigel in Capan-I pancreatic cancer cells. BMC Gastroenterol 2005, 5: I 2.

24. Schlaepfer DD, Hunter T: FAK overexpression enhances Rasdependent integrin signaling to ERK2/mitogen-activated protein kinase through interactions with and activation of cSrc. J Biol Chem 1997, 272:13189-13195. 
25. Schaller MD, Hildebrand JD, Shannon JD, Fox JW, Vines RR, Parsons JT: Autophosphorylation of the focal adhesion kinase, pp I 25FAK, directs SH2-dependent binding of pp60src. Mol Cell Biol 1994, 14:1680-1688.

26. Sakamoto M, Ino Y, Ochiai A, Kanai Y, Akimoto S, Hirohashi S: Formation of focal adhesion and spreading of polarized human colon cancer cells in association with tyrosine phosphorylation of paxillin in response to phorbol ester. Lab lnvest 1996, 74:199-208.

27. Walker HA, Whitelock JM, Garl PJ, Nemenoff RA, Stenmark KR, Weiser-Evans MC: Perlecan up-regulation of FRNK suppresses smooth muscle cell proliferation via inhibition of FAK signaling. Mol Biol Cell 2003, I 4: 194I-1952.

28. Tamura M, Gu J, Tran H, Yamada KM: PTEN gene and integrin signaling in cancer. J Natl Cancer Inst 1999, 91:1820-1828.

29. Wu RC, Blumenthal M, Li X, Schonthal AH: Loss of cellular adhesion to matrix induces p53-independent expression of PTEN tumor suppressor. BMC Mol Biol 2002, 3: II.

30. Zhang L, Yu Q, He J, Zha X: Study of the PTEN gene expression and FAK phosphorylation in human hepatocarcinoma tissues and cell lines. Mol Cell Biochem 2004, 262:25-33.

31. Sebolt-Leopold JS, Dudley DT, Herrera R, Van Becelaere K, Wiland A, Gowan RC, Tecle H, Barrett SD, Bridges A, Przybranowski S, Leopold WR, Saltiel AR: Blockade of the MAP kinase pathway suppresses growth of colon tumors in vivo. Nat Med 1995, 5:810-816.

32. Ahmed N, Oliva K, Wang Y, Quinn M, Rice G: Downregulation of urokinase plasminogen activator receptor expression inhibits Erk signalling with concomitant suppression of invasiveness due to loss of uPAR-betal integrin complex in colon cancer cells. BrJ Cancer 2003, 89:374-384.

33. Okada Y, Eibl G, Guha S, Duffy JP, Reber HA, Hines OJ: Nerve growth factor stimulates MMP-2 expression and activity and increases invasion by human pancreatic cancer cells. Clin Exp Metastasis 2004, 21:285-292.

34. Lin M, DiVito MM, Merajver SD, Boyanapalli M, van Golen KL: Regulation of pancreatic cancer cell migration and invasion by RhoC GTPase and caveolin-I. Mol Cancer 2005, 4:2I.

35. Yoshida S, Ujiki M, Ding XZ, Pelham C, Talamonti MS, Bell RH Jr, Denham W, Adrian TE: Pancreatic Stellate Cells (PSCs) Express Cyclooxygenase-2 (COX-2) and Pancreatic Cancer Stimulates COX-2 in PSCs. Mol Cancer 2005, 4:27.

36. Renshaw MW, Price LS, Schwartz MA: Focal adhesion kinase mediates the integrin signaling requirement for growth factor activation of MAP kinase. / Cell Biol 1999, | 47:6 | |-618.

37. Zhang L, Bewick M, Lafrenie RM: Role of Raf- $I$ and FAK in cell density dependent regulation of integrin dependent activation of MAP kinase. Carcinogenesis 2002, 23: | 25|-|258.

38. Klemke RL, Cai S, Giannini AL, Gallagher PJ, de Lanerolle P, Cheresh $D A$ : Regulation of cell motility by mitogen-activated protein kinase. I Cell Biol 1997, I 37:48I-492.

39. Ilic D, Furuta $Y$, Kanazawa S, Takeda N, Sobue K, Nakatsji N, Nomur S, Fujimoto J, Okada M, Yamamoto T: Reduced cell motility and enhanced focal adhesion contact formation in cells from FAK-deficient mice. Nature 1995, 377:539-544.

40. Gilmore AP, Romer LH: Inhibition of focal adhesion kinase (FAK) signaling in focal adhesions decreases cell motility and proliferation. Mol Biol Cell 1996, 7:। 209-1224.

4I. Hungerford JE, Compton MT, Matter ML, Hoffstrom BG, Otey CA: Inhibition of ppI25FAK in cultured fibroblasts results in apoptosis. J Cell Biol 1996, I35:1383-1390.

42. Xu LH, Owens LV, Sturge GC, Yang X, Liu ET, Craven RJ, Cance WG: Attenuation of the expression of the focal adhesion kinase induces apoptosis in tumor cells. Cell Growth Differ 1996, 7:413-418.

43. Liu XJ, Yang L, Wu HB, Qiang O, Huang MH, Wang YP: Apoptosis of rat hepatic stellate cells induced by anti-focal adhesion kinase antibody. World J Gastroenterol 2002, 8:734-738.

44. Kurenova E, Xu LH, Yang X, Baldwin AS Jr, Craven RJ, Hanks SK, Liu ZG, Cance WG: Focal adhesion kinase suppresses apoptosis by binding to the death domain of receptor-interacting protein. Mol Cell Biol 2004, 24:436I-437I.

45. Duxbury MS, Ito H, Zinner MJ, Ashley SW, Whang EE: Focal adhesion kinase gene silencing promotes anoikis and suppresses metastasis of human pancreatic adenocarcinoma cells. Surgery 2004, 135:555-562.
46. Vidal-Vanaclocha F, Amezaga C, Asumendi A, Kaplanski G, Dinarello $C A$ : Interleukin-I receptor blockade reduces the number and size of murine B 16 melanoma hepatic metastases. Cancer Res 1994, 54:2667-2672.

47. Chirivi RG, Chiodoni C, Musiani P, Garofalo A, Bernasconi S, Colombo MP, Giavazzi R: IL-I alpha gene-transfected human melanoma cells increase tumor-cell adhesion to endothelial cells and their retention in the lung of nude mice. Int J Cancer 1996, 67:856-863.

48. Voronov E, Shouval DS, Krelin Y, Cagnano E, Benharroch D, Iwakura Y, Dinarello CA, Apte RN: IL-I is required for tumor invasiveness and angiogenesis. Proc Natl Acad Sci 2003, 100:2645-2650.

49. Fan XM, Wong BC, Lin MC, Cho CH, Wang WP, Kung HF, Lam SK: Interleukin-Ibeta induces cyclo-oxygenase-2 expression in gastric cancer cells by the p38 and p44/42 mitogen-activated protein kinase signaling pathways. J Gastroenterol Hepatol 200 I, 16:1098-II04.

50. Kida Y, Kobayashi M, Suzuki T, Takeshita A, Okamatsu Y, Hanazawa $\mathrm{S}$, Yasui T, Hasegawa K: Interleukin-I stimulates cytokines, prostaglandin E2 and matrix metalloproteinase-I production via activation of MAPK/AP-I and NF-kappaB in human gingival fibroblasts. Cytokine 2005, 29:159-168.

5I. Wang Q, Downey GP, Bajenova E, Abreu M, Kapus A, McCulloch CA Mitochondrial function is a critical determinant of IL-I. induced ERK activation. FASEB J 2005, 19:837-839.

52. Miyamoto S, Teramoto H, Coso OA: Integrin function: molecular hierarchies of cytoskeletal and signaling molecules. J Cell Biol 1995, | 3 I:791-805.

53. Clark EA, Hynes RO: Ras activation is necessary for integrinmediated activation of extracellular signal regulated kinase 2 and cytosolic phospholipase A2 but not for cytoskeletal organization. J Biol Chem 1996, 27 I: | 48|4-|48|8.

54. Jung YD, Fan F, McConkey DJ, Jean ME, Liu W, Reinmuth N, Stoeltzing O, Ahmad SA, Parikh AA, Mukaida N, Ellis LM: Role of P38 MAPK, AP-I, and NF-KB in interleukin-I $\beta$-induced IL-8 expression in human vascular smooth muscle cells. Cytokine 2002, 8:206-2I3.

55. Shehata MF: Rel/Nuclear factor-kappa B apoptosis pathways in human cervical cancer cells. Cancer Cell Int 2005, 5:10.

56. Sgonc R, Gruber J: Apoptosis detection: an overview. Exp Gerontol 1998, 33:525-533.

Publish with Bio Med Central and every scientist can read your work free of charge

"BioMed Central will be the most significant development for disseminating the results of biomedical research in our lifetime. "

Sir Paul Nurse, Cancer Research UK

Your research papers will be:

- available free of charge to the entire biomedical community

- peer reviewed and published immediately upon acceptance

- cited in PubMed and archived on PubMed Central

- yours - you keep the copyright

Submit your manuscript here:

http://www.biomedcentral.com/info/publishing_adv.asp
BiolMedcentral 